\title{
Batrachochytrium dendrobatidis in amphibians confiscated from illegal wildlife trade and used in an ex situ breeding program in Brazil
}

\author{
C. D. De Paula ${ }^{1, *}$, E. C. Pacífico-Assis ${ }^{2}$, J. L. Catão-Dias ${ }^{1}$ \\ ${ }^{1}$ Departamento de Patologia, Faculdade de Medicina Veterinária e Zootecnia, Universidade de São Paulo, São Paulo, SP, Brazil \\ ${ }^{2}$ Departamento de Zoologia, Instituto de Biociências, Universidade de São Paulo, São Paulo, SP, Brazil
}

\begin{abstract}
This paper describes an outbreak of chytridiomycosis affecting a group of Dendrobates tinctorius, a Neotropical anuran species, confiscated from the illegal wildlife trade and housed in a private zoo in Brazil as part of an ex situ breeding program. We examined histological sections of the skin of $30 \mathrm{D}$. tinctorius and 20 Adelphobates galactonotus individuals. Twenty $D$. tinctorius $(66.7 \%)$ and none of the A. galactonotus were positive for Batrachochytrium dendrobatidis $(B d)$. Multiple development stages of $B d$ infection were observed. The reasons for the interspecific difference in the rate of infection could not be determined, and further studies are advised. Because the examined population consisted of confiscated frogs, detailed epidemiological aspects could not be investigated, and the source of the fungus remains uncertain. The existence of ex situ amphibian populations is important for protecting species at higher risk in the wild, and ex situ amphibian conservation and breeding programs in Brazil may be established using confiscated frogs as founders. However, this paper alerts these programs to the urgency of strict quarantine procedures to prevent the introduction of potential pathogens, particularly $B d$, into ex situ conservation programs.
\end{abstract}

KEY WORDS: Chytridiomycosis $\cdot$ Dendrobates tinctorius $\cdot$ Neotropical anuran $\cdot$ Brazil

\section{INTRODUCTION}

Dramatic declines among amphibian populations worldwide have occurred in recent decades (Stuart et al. 2004). Many causes have been suggested, including habitat loss, invasive species, overexploitation, climate change, environmental contaminants and infectious diseases (Gardner 2001, Blaustein \& Kiesecker 2002, Stuart et al. 2004). Brazil has the world's greatest amphibian diversity with more than 860 species, most of which were described in the last 40 yr (SBH 2010). There are few reports of amphibian population declines in Brazil, and most involve highaltitude species (Eterovick et al. 2005, Silvano \& Segalla 2005). There are 116 Brazilian amphibian species in the International Union for Conservation of Nature (IUCN) Red List (IUCN 2008), and the Brazilian government lists 16 species as threatened, 1 species as extinct and 90 species as data deficient (Haddad 2008). There is insufficient information to evaluate the conservation status of more than $10 \%$ of the Brazilian amphibians and a general lack of information about the species that are either threatened or data deficient (Pistoni \& Toledo 2010).

Chytridiomycosis, which is caused by the chytrid fungus Batrachochytrium dendrobatidis $(B d)$, is a devastating emerging infectious disease that infects a high diversity of amphibian species and is considered responsible for massive amphibian declines and extinctions. It has been reported in wild populations 
in several regions throughout the world, including South America (Daszak et al. 2003, Morehouse et al. 2003, Lips et al. 2005, Lips et al. 2006). The first evidence of infection in wild frogs in Brazil was reported in Hylodes magalhaesi, a leptodactylid from the Atlantic Rain Forest (Carnaval et al. 2005). Later investigations revealed that $B d$ was broadly distributed in that biome, infecting another 5 species (Carnaval et al. 2006, Toledo et al. 2006). It has also been described in farmed, captive Lithobates catesbeianus in Brazil (Schloegel et al. 2010).

$B d$ is a member of the Phylum Chytridiomycota and the first chytrid fungus to be recognized as a parasite of the Phylum Vertebrata (Berger et al. 1998). It infects keratinized cells in amphibians (the mouthparts of larvae and the epidermis of adults) and leads to hyperkeratosis (Pessier et al. 1999). The pathogenesis of $B d$ is controversial; however, Voyles et al. (2009) demonstrated that electrolytic transport in the skin was inhibited by $>50 \%$, plasma sodium and potassium concentrations were reduced, and asystolic cardiac arrest resulted in death in diseased green tree frogs Litorea caerulea. Because the skin is critical for amphibian homeostasis, disruption of cutaneous function may cause morbidity and mortality in a wide range of amphibians.

The diagnosis of $B d$ can be obtained through histopathological demonstration of the zoospore in the epidermis of infected anurans (Pessier et al. 1999). Variable amounts of keratin may closely surround the organism (Berger et al. 2000). The main histopathological change in the skin is mild to moderate hyperkeratosis. Irregular hyperplasia may be present, as well as mild focal necrosis of the epidermal cells. Occasional ulcerations can be seen and are generally associated with secondary bacterial infection. Inflammation is an inconsistent finding. There is extensive involvement of the ventral skin and toes (Pessier et al. 1999, Berger et al. 2000, 2005). Other diagnostic methods include immunohistochemistry (Van Ells et al. 2003), electron microscopy (Berger et al. 2002), conventional PCR (Annis et al. 2004) and real-time PCR (Boyle et al. 2004).

Despite the threats to its rich amphibian diversity, Brazil has very few captive populations or ex situ conservation programs involving these vertebrates. This situation may change rapidly because several species are facing threats that cannot be solved solely with the in situ conservation strategies currently available. The existence of ex situ amphibian populations is important to protect species that are at higher risk in the wild until the threats can be reduced, and the establishment of captive breeding facilities is considered an important strategy for responding to the amphibian conservation crisis. In this scenario, zoological institutions may play an important role in preventing the spread of the disease throughout captive facilities as well as in disease surveillance, research, and captive breeding and reintroduction programs (Gascon et al. 2007). This paper describes an outbreak of chytridiomycosis affecting a group of Dendrobates tinctorius, a Neotropical anuran species, that originated from an illegal trade apprehension and were subsequently housed in a private zoo in Brazil. Implications for in situ and ex situ conservation programs are briefly discussed.

\section{CASE REPORT}

We examined formalin-fixed specimens of 30 Dendrobates tinctorius and 20 Adelphobates galactonotus that had died between 2005 and 2009 in a private zoo in São Paulo State, Brazil. Some animals died without previous clinical signs, while others presented progressive emaciation. The animals were received from local authorities after an illegal trade apprehension and were housed off-exhibit in the same room and in close proximity to each other in several glass vivaria. Additional information regarding shipment conditions was not available. Room temperature was maintained at approximately $25^{\circ} \mathrm{C}$, and the relative humidity ranged from 60 to $80 \%$. The vivaria had an expanded clay substrate with plants and coconut shells to provide shelter. The dead animals were fixed in $10 \%$ formalin and submitted for histopathological examination at the Laboratório de Patologia Comparada de Animais Selvagens - Departamento de Patologia, Faculdade de Medicina Veterinária e Zootecnia - Universidade de São Paulo, Brazil. Skin sections from the digits of the front and rear limbs and from the lower abdomen were embedded in paraffin, cut into $5 \mu \mathrm{m}$ sections, stained with hematoxylin and eosin (H\&E) and then examined under light microscopy. Attempts to extract DNA for molecular diagnosis of $B d$ infection by conventional PCR were performed using the Invitrogen Pure Link Genomic DNA kit according to the manufacturer's recommendations. Complementary microbiological exams were not performed because the carcasses were already in formalin solution when they were received.

Twenty Dendrobates tinctorius (66.7\%) and none of the Adelphobates galactonotus (0\%) were positive for $B d$ based on histological diagnosis. Various development stages of $B d$ infection were observed within 
the stratum corneum, including zoosporangia with zoospores and empty zoosporangia with internal septation (Fig. 1). Hyperkeratosis was also observed, but no inflammatory response was seen in the epidermis or in the underlying dermis. Attempts to extract DNA were unsuccessful.

\section{DISCUSSION}

The Amphibian Conservation Action Plan (ACAP) states that the amphibian extinction crisis requires a global response from governments, corporations, civil society and the scientific community and reinforces the importance of establishing surviving and healthy ex situ populations to preserve the option to re-introduce species to their native habitat if needed (Gascon et al. 2007). With the initiative and support of the Amphibian Ark (www.amphibianark.org), attempts have been made to improve and stimulate amphibian ex situ conservation in Brazil in recent years. Infectious diseases, such as chytridiomycosis, have become an important factor for amphibian conservation and must be seriously considered in captive breeding and reintroduction programs. Facilities maintaining captive amphibians should be responsible for implementing infectious disease surveillance and control measures to prevent the introduction of pathogens to native locations or populations (Pessier \& Mendelson 2010). In fact, a situation was recently reported in a re-introduction program for the Mallorcan midwife toad Alytes muletensis, in which a $B d$ infection had not

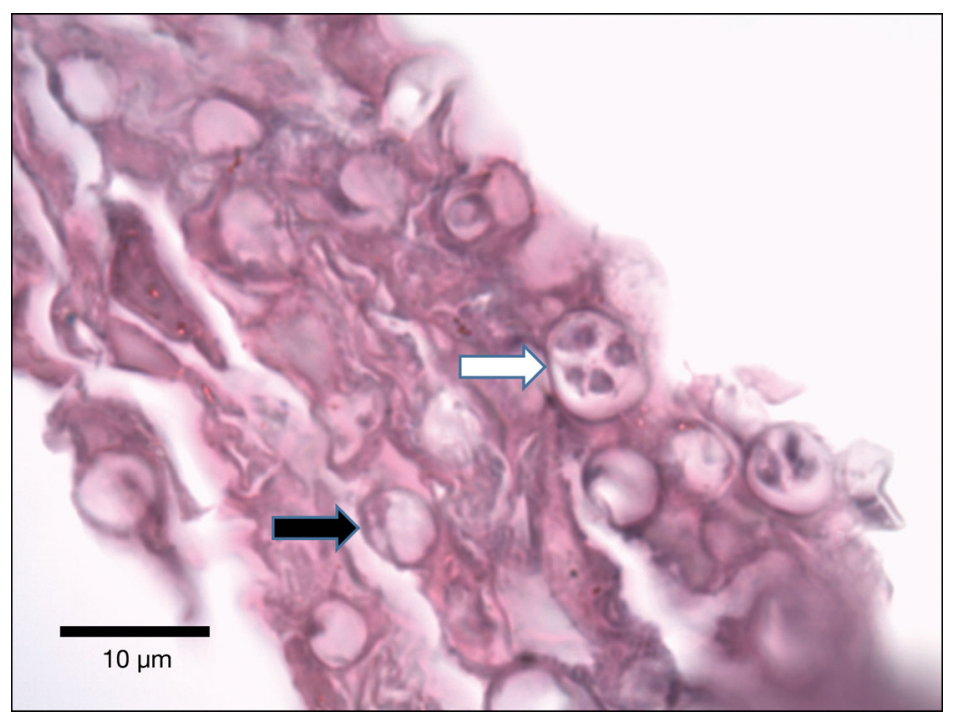

Fig. 1. Photomicrograph of the epidermal keratin of Dendrobates tinctorius. Note the presence of zoosporangia with zoospores (white arrow) and empty zoosporangia (black arrow). H\&E stained been detected in the ex situ population, and the fungus was accidentally introduced to the wild population (Walker et al. 2008). Situations like this reinforce the need to strictly follow the IUCN guidelines for captive breeding and reintroduction projects (IUCN 1998).

In Brazil, $B d$ has already been identified in asymptomatic captive North American bullfrogs Lithobates catesbeianus, with an overall prevalence of $78.5 \%$. Recent studies showed a marked similarity in Latin American $B d$ isolates from captive bullfrogs, wild bullfrogs and wild native frogs. This similarity suggests that there is or has been transmission among populations and/or that the infections came from a common source (Schloegel et al. 2010).

The findings reported herein provide evidence that $B d$ is also present in captive zoo populations of anuran amphibians in Brazil and indicates the urgent need to implement strict biosecurity measures in such facilities. After the disease was identified in the studied amphibian collection, biosecurity measures, such as rigorous quarantine, testing and husbandry practices, were strongly recommended (Pessier \& Mendelson 2010), and medical treatment was indicated for the remaining animals $(0.01 \%$ itraconazole in $0.6 \%$ saline solution, in 5 min baths for 11 consecutive days, as recommended by Forzán et al. 2008 and Pessier \& Mendelson 2010). Apparently, after the treatment, there was a decrease in the mortality rate, but unfortunately, no complementary data regarding the efficacy of the medical treatment were available.

The examined population consisted of confiscated animals originating from the illegal wildlife trade, and therefore, the source of the fungus remains uncertain. According to Brazilian environmental regulations, confiscated animals may be used as founders for conservation-oriented captive populations. Because ecological, sanitary and epidemiological data on confiscated animals is scarce, our results emphasize that the use of apprehended specimens to establish captive populations requires the implementation of strict quarantine procedures. The available information on $B d$ suggests that the current fungus distribution was caused by the movement of infected specimens from a yet unidentified source population in the early half of the 20th century (Fisher et al. 2009). In this scenario, legal and/or illegal wildlife trade may be an important route for pathogen spread. Although habitat loss is the main conservation threat to amphibians in Brazil, illegal trade in wildlife originating in Brazil is estimated to account for 10 to $15 \%$ of the 
worldwide illegal wildlife commerce, and there is little information on the status of amphibians within this trade in Brazil (Pistoni \& Toledo 2010). Amphibians are among the easiest vertebrates to smuggle in large numbers (Garner et al. 2009). It is believed that this illegal practice has contributed to the international spread of amphibian pathogens, notably $B d$, which, together with ranaviruses, has been considered by the World Organization for Animal Health (OIE) to be a pathogen of particular importance in the international trade of amphibians (Kriger \& Hero 2009, Schloegel et al. 2010). The amphibian trade may increase the geographic distribution of the pathogen to regions that are currently free of $B d$ and may introduce new strains of the fungus, as previous studies have illustrated important differences in the pathogenicity among isolates (Berger et al. 2005, Retallick \& Miera 2007).

In this study, despite the fact that both species were housed in the same room and no specific measures were taken to prevent pathogen dissemination, $B d$ was reported to affect $66.7 \%$ of the Dendrobates tinctorius specimens but none of the Adelphobates galactonotus specimens. Reasons for the difference in $B d$ infection between the 2 species could not be determined, and further studies are advised. However, a broad range of possible mechanisms may be involved, including differences in host defenses, such as secretions of antimicrobial peptides or bacterial commensals with anti-fungal properties (Blaustein et al. 2005, Rollins-Smith \& Conlon 2005, Harris et al. 2006, Woodhams et al. 2006, Chinnadurai et al. 2009), and/or the number or strain of infecting zoospores with potentially varying contact rates (Carey et al. 2006).

Another possibility is the low sensitivity of the diagnostic method used. Histopathology of skin is an adequate diagnostic method for moderate to massive $B d$ infection; however, it is not sensitive enough to reliably detect a subclinical infection (Pessier 2008). The available data do not allow the exclusion of the possibility that mild $B d$ infection in Adelphobates galactonotus was undiagnosed. According to Olsen et al. (2004), the occurrence of false-negative microscopic diagnosis in affected animals can occur when $B d$ zoosporangia are shed with the superficial keratin layers. While we cannot be entirely certain this was not the case for the examined A. galactonotus, we consider it to be highly unlikely because the keratin was well preserved in most of the examined skin samples, and no zoosporangia were observed. Molecular assays, particularly real-time PCR performed on DNA collected by swabbing the ventral body, are considered the most sensitive and broadly recommended diagnostic method. Unfortunately, in this case, the attempts to extract DNA for molecular testing were unsuccessful, probably because the carcasses had been kept in formalin for at least $1 \mathrm{yr}$.

In this paper, we described chytridiomycosis affecting Dendrobates tinctorius confiscated from the illegal trade and kept in a private zoo in Brazil. Considering that amphibian ex situ conservation and breeding programs in Brazil may be established using confiscated animals as founders, this paper alerts these programs to the urgency of strict quarantine procedures to prevent the introduction of potential pathogens, particularly $B d$, as well as to the threat that the wildlife trade can cause by spreading the disease.

Acknowledgements. The authors express their sincere appreciation to the Fundação de Amparo à Pesquisa do Estado de São Paulo (FAPESP, grant no. 09/52638-3) and the Coordenação de Aperfeiçoamento de Pessoal de Nível Superior (CAPES). J.L.C.D. is a recipient of a professorship from the Conselho Nacional de Desenvolvimento Científico e Tecnológico (CNPq, 301517/2006-1). This study was conducted by C.D.D.P. as partial fulfillment of the requirements for a doctorate degree at the Departamento de Patologia, Faculdade de Medicina Veterinária e Zootecnia, Universidade de São Paulo. Thanks to Allan Pessier from the Wildlife Disease Laboratories, San Diego Zoological Society, for his assistance with the histopathological diagnosis.

\section{LITERATURE CITED}

Annis SL, Dastoor FP, Ziel H, Daszak P, Longcore JE (2004) A DNA-based assay identifies Batrachochytrium dendrobatidis in amphibians. J Wildl Dis 40:420-428

Berger L, Speare R, Daszak P, Green DE and others (1998) Chytridiomycosis causes amphibian mortality associated with population declines in the rain forests of Australia and Central America. Proc Natl Acad Sci USA 95: 9031-9036

Berger L, Speare R, Kent A (2000) Diagnosis of chytridiomycosis in amphibians by histological examination. Zoos Print J 15:184-190

Berger L, Hyatt AD, Olsen V, Hengstberger SG and others (2002) Production of polyclonal antibodies to Batrachochytrium dendrobatidis and their use in an immunoperoxidase test for chytridiomycosis in amphibians. Dis Aquat Org 48:213-220

Berger L, Speare R, Skerrat LF (2005) Distribution of Batrachochytrium dendrobatidis and the pathology of the skin of green tree frogs Litoria caerulea with severe chytridiomycosis. Dis Aquat Org 68:65-70

Blaustein AR, Kiesecker JM (2002) Complexity in conservation: lessons from the global decline of amphibian populations. Ecol Lett 5:597-608

> Blaustein AR, Romansic JM, Scheessele EA, Han BA, Pessier AP, Longcore JE (2005) Interspecific variation in susceptibility of frog tadpoles to the pathogenic fungus Batrachochytrium dendrobatidis. Conserv Biol 19: 1460-1468 
Boyle DG, Boyle DB, Olsen V, Morgan JAT, Hyatt AD (2004) Rapid quantitative detection of chytridiomycosis (Batrachochytrium dendrobatidis) in amphibian samples using real-time Taqman PCR assay. Dis Aquat Org 60:141-148

Carey C, Bruzgal JE, Livo LJ, Walling ML and others (2006) Experimental exposures of Boreal toads (Bufo boreas) to a pathogenic chytrid fungus (Batrachochytrium dendrobatidis). EcoHealth 3:5-21

Carnaval ACOQ, Toledo LF, Haddad CFB, Britto FB (2005) Chytrid fungus infects high-altitude steam-dwelling Hylodes magalhaesi (Leptodactylidae) in the Brazilian Atlantic Rainforest. FrogLog 70:3-4, available at www. amphibians.org/blog/2011/08/30/froglog70

> Carnaval ACOQ, Puschendorf R, Peixoto OL, Verdade VK, Rodriguês MT (2006) Amphibian chytrid fungus broadly distributed in the Brazilian Atlantic Rain Forest. EcoHealth 3:41-48

Chinnadurai SK, Cooper D, Dombrowski DS, Poore MF, Levy MG (2009) Experimental infection of native North Carolina salamanders with Batrachochytrium dendrobatidis. J Wildl Dis 45:631-636

> Daszak P, Cunningham AA, Hyatt AD (2003) Infectious diseases and amphibian population decline. Divers Distrib 9:141-150

Eterovick PC, Carnaval ACOQ, Borges-Nojosa DM, Silvano DL, Segalla MV, Sazima I (2005) Amphibian declines in Brazil: an overview. Biotropica 37:166-179

Fisher MC, Garner TWJ, Walker SF (2009) Global emergence of Batrachochytrium dendrobatidis and amphibian chytridiomycosis in space, time and host. Annu Rev Microbiol 63:291-310

> Forzán MJ, Gunn H, Scott P (2008) Chytridiomycosis in an aquarium collection of frogs: diagnosis, treatment, and control. J Zoo Wildl Med 39:406-411

Gardner T (2001) Declining amphibian populations: global phenomenon in conservation biology. Anim Biodiversity Conserv 24:25-44

Garner TWJ, Stephen I, Wombwell E, Fisher MC (2009) The amphibian trade: bans or best practice? EcoHealth 6: 148-151

Gascon C, Collins JP, Moore RD, Church DR, Mckay J, Mendelson J III (2007) Amphibian conservation action plan. IUCN/SSC Amphibian Specialist Group, Gland

Haddad CFB (2008) Uma análise da lista brasileira de anfíbios ameaçados de extinção. In: Machado ABM, Drummond GM, Paglia AP (eds) Livro vermelho da fauna Brasileira ameaçada de extinção, Vol II. Ministério do Meio Ambiente, Brasilia, p 287-295

- Harris RN, James TY, Lauer A, Simon HA, Patel A (2006) Amphibian pathogen Batrachochytrium dendrobatidis is inhibited by cutaneous bacteria of amphibians species. EcoHealth 3:53-56

IUCN (International Union for Conservation of Nature) (1998) Guidelines for reintroductions. IUCN/SSP Reintroduction Species Specialist Group, Gland

IUCN (International Union for Conservation of Nature) (2008) IUCN Red List of threatened species, Ver 2010.2. Available at www.iucnredlist.org (accessed 15 January 2011)

- Kriger KM, Hero JM (2009) Chytridiomycosis, amphibian extinctions, and lessons for the prevention of future panzootics. EcoHealth 6:6-10

Lips KR, Burrowes PA, Mendelson JR III, Parra-Olea G (2005) Amphibian declines in Latin America: widespread population declines, extinctions and impacts. Biotropica 37:163-165

Lips KR, Brem F, Brenes R, Reeve JD and 6 others (2006) Emerging infectious disease and the loss of biodiversity in a Neotropical amphibian community. Proc Natl Acad Sci USA 103:3165-3170

Morehouse EA, James TY, Ganley ARD, Vilgays R, Berger L, Murphy PJ, Longcore JE (2003) Multilocus sequence typing suggests the chytrid pathogen of amphibians is a recently emerged clone. Mol Ecol 12:395-403

Olsen V, Hyatt AD, Boyle DG, Mendez D (2004) Co-localisation of Batrachochytrium dendrobatidis and keratin for enhanced diagnosis of chytridiomycosis in frogs. Dis Aquat Org 61:85-88

Pessier AP, Mendelson JR (eds) (2010) A manual for control of infectious disease in amphibian survival assurance colonies and reintroduction programs. IUCN/SSC Conservation Breeding Specialist Group, Apple Valley, MN

Pessier AP, Nichols DK, Langcore JE, Fuller MS (1999) Cutaneous chytridiomycosis in poison dart frog (Dendrobates spp.) and White's tree frog (Litoria caerulea). J Vet Diagn Invest 11:194-199

Pessier AP (2008) Management of disease as a threat to amphibian conservation. Int Zoo Yearb 42:30-39

> Pistoni J, Toledo LF (2010) Amphibian illegal trade in Brazil: What do we know? S Am J Herpetol 5:51-56

Retallick RWR, Miera V (2007) Strain differences in the amphibian chytrid fungus Batrachochytrium dendrobatidis and non-permanent, sub-lethal effects of infection. Dis Aquat Org 75:201-207

Rollins-Smith LA, Conlon JM (2005) Antimicrobial peptide defense against chytridiomycosis, an emerging infectious disease of amphibian populations. Dev Comp Immunol 29:589-598

SBH (Sociedade Brasileira de Herpetologia) (2010) Lista oficial de espécies de anfíbios do Brasil. www.sbherpetologia. org.br/checklist.thm (accessed 14 November 2010)

- Schloegel LM, Ferreira CM, James TY, Hipolito M and 7 others (2010) The North American bullfrog as a reservoir for the spread of Batrachochytrium dendrobatidis in Brazil. Anim Conserv 13:53-61

Silvano DL, Segalla MV (2005) Conservation of Brazilian amphibians. Conserv Biol 19:653-658

Stuart SN, Chanson JS, Cox NA, Young BE, Rodrigues ASL, Fischman DL, Waller RW (2004) Status and trends of amphibian declines and extinctions worldwide. Science 306:1783-1786

> Toledo LF, Britto FB, Araujo OGS, Giasson LMO, Haddad CFB (2006) The occurrence of Batrachochytrium dendrobatidis in Brazil and the inclusion of 17 new cases of infection. S Am J Herpetol 1:185-191

Van Ells T, Stanton JS, Strieby A, Daszak P, Hyatt AD, Brown C (2003) Use of immunohistochemistry to diagnose chytridiomycosis in dying poison dart frogs (Dendrobates tinctorius). J Wildl Dis 39:742-745

- Voyles J, Young S, Berger L, Campbell C and others (2009) Pathogenesis of chytridiomycosis, a cause of catastrophic amphibian decline. Science 326:582-585

Walker SF, Bosch J, James TY, Litvintseva AP and others (2008) Invasive pathogen threaten species recovery programs. Curr Biol 18:R853-R854

Woodhams DC, Voyles J, Lips KR, Carey C, Rollins-Smith LA (2006) Predicted disease susceptibility in Panamanian amphibian based on skin peptide defenses. J Wildl Dis 42:207-218 